\title{
Garifunizando Ambas Américas: Hemispheric Entanglements of Blackness/Indigeneity/AfroLatinidad
}

Paul Joseph López Oro

Smith College, plopezoro@smith.edu

Follow this and additional works at: https://scholarworks.smith.edu/afr_facpubs

Part of the Africana Studies Commons

\section{Recommended Citation}

López Oro, Paul Joseph, "Garifunizando Ambas Américas: Hemispheric Entanglements of Blackness/ Indigeneity/AfroLatinidad" (2020). Africana Studies: Faculty Publications, Smith College, Northampton, MA.

https://scholarworks.smith.edu/afr_facpubs/16

This Article has been accepted for inclusion in Africana Studies: Faculty Publications by an authorized administrator of Smith ScholarWorks. For more information, please contact scholarworks@smith.edu 
Garifunizando Ambas Américas: Hemispheric Entanglements of Blackness/Indigeneity/AfroLatinidad

Paul Joseph López Oro

Abstract: Central Americans of African descent are in the margins on the histories of transmigrations and political movements in the isthmus and their diasporas. The absence of Black Central Americans in Latinx Studies and Central American Studies is an epistemological violence inherited from Latin American mestizaje. The insurgence of Afro-Latinx Studies is an intellectual and political response to the erasure and negation of Black people and Blackness in the field of Latinx Studies. In this essay, I map out the political urgency to call for a refashioning of Afrolatinidad that dismantles the dangerous allure of ethno-racial nationalism (i.e., Afro[insert nation-state]) and mappability of Blackness into exclusionary geographies of Spanishspeaking Americas (i.e., “you must be Dominican, because you don't look Guatemalan”). Drawing on oral history interviews, visual cultures, and social media analysis, I demonstrate how transgenerational Garifuna New Yorkers of Central American descent histories and politics of self-making, beginning in the late 1950s to the present, highlight their negotiations and contradictions as they perform their multiple subjectivities as Black, Indigenous, and AfroLatinx.

When I am challenged or questioned about my identity, I respond by saying that Black people exist in Central America. Some are descendants of enslaved peoples; some are not. Some speak Spanish; some do not. Some are Catholic; some are Rastas; some are Garveyites. Some are immersed in hybridized identities that include native, Asian, and African 
nations. And when these Black people come to the United States, they continue to be Black people from Central America, negotiating among invisibilities.

--Vielka Cecilia Hoy, "Negotiating among Invisibilities"

In the United States, the invocation of Central America conjures a set of racial and political imaginaries that centers mestizos, Indigenous cultures, revolutionary movements, civil wars, and US occupations, eclipsing a discussion of race and racism in the region and its diasporas. Within Central American mestizaje, Blackness is relegated and ascribed to the Caribbean Coast, erasing centuries of Black folks in the interior and Pacific Coasts. By ascribing Blackness and Black people to Central America's Caribbean Coasts, mestizaje constructs its imaginary in opposition to and as a negation of Blackness, especially when the Caribbean Coast is understood to be removed from the national public spaces of mestizo governance, for example with Managua or Tegucigalpa. Moreover, this imaginary renders Central American Blackness as Caribbean, as coming from elsewhere and not always already present prior to the formation of the Republic. More recently, Central American neoliberal multiculturalism (Hale) constructs Blackness as a folkloric caricature for tourist and popular culture consumption (Loperena). Black Central Americans doubly negotiate their invisibilities on the isthmus and in their diasporas in the United States. Despite the extensive and rich history of Africans and their descendants in the isthmus, especially their presence and contributions centuries prior to the 1821 Wars of Independence, Black history and Blackness remain alien to Central American nationhood in and outside of the isthmus (Gudmundson and Wolfe 5). This negation and erasure of Black Central Americans is produced and preserved by the dominant nationalist racial project of racial mixture or mestizaje. 
Black Central Americans transgenerationally carry with them when they migrate to the United States centuries of embodied histories of anti-black racism and violence. ${ }^{1}$

Vielka Cecilia Hoy’s essay “Negotiating among Invisibilities: Tales of Afro-Latinidades in the United States" appeared in the trailblazing volume The Afro-Latin@,Reader: History and Culture in the United States. Vielka's essay is one of three essays in the 584-page volume that is written from and about a Black Central American worldview. Born in Brooklyn, New York, Vielka Cecilia Hoy was raised in Oakland, California, by immigrant parents. Her mother is a Creole Nicaraguan woman from Bluefields and her father is an Afro-Panamanian man from Colón and a descendant of West Indian migrant workers. Her essay powerfully illustrates the nuances and complex ways her Black Latinidad is in perpetual conflict in a space like the West Coast, where the dominance of mestizo Mexican identities and cultures shapes the Californian imaginary as a Mexican/Chicanx/Mexican-American space of Latinidad. In similar ways on the East Coast, specifically in New York City as a Caribbean Latinx city, AfroLatinx peoples are often assumed to be Dominican, whereas Black Central Americans tend to be racialized as African Americans or West Indians. Hoy's essay is striking because of the multiplicity of invisibilities and contradictions it engages. It is here, in the space of negotiations, contradictions, and articulations that I consider the ways transgenerational Garifuna New Yorkers exist, live, and articulate their multiple Black, Indigenous, and Latinidad subjectivities.

Garifuna are Black Indigenous peoples who are descendants of shipwrecked enslaved West Africans and autochthonous Carib-Arawak on the Caribbean island of St. Vincent. Their exile by British colonial powers in 1797 to the Bay Islands of Honduras and their subsequent migrations to Belize, Guatemala, Nicaragua, and mainland Honduras script their ethnogenesis in the lesser Antillean Caribbean and mark their multiple diasporas: African, Caribbean, and 
Central American (England). With the economic collapse of the United Fruit Company in the mid-twentieth century, Garifuna Central Americans commenced multiple waves of transgenerational migration to major US port cities such as New York City, New Orleans, Miami, Chicago, Boston, and San Francisco. This migration continues today, as gang violence, government corruption, and economic instability dominate the Central American region. A diasporic multiplicity informs the complex ways in which Garifuna negotiate their multiple subjectivities in Central America and in the United States, as Central America's Caribbean Coasts become nostalgic sites of home whose Black Indigeneity imagines St. Vincent as homeland. ${ }^{2}$ Garifuna Black Indigeneity unsettles racial formations in the Americas that understand Blackness, Indigeneity, and Latinidad as mutually exclusive.

In the context of Belize, Guatemala, Honduras, and Nicaragua, where Garifuna and Creole communities have lived prior to 1821, mestizaje discursively emerges as an ideological project of nation-building, violently negating Blackness and the existence and contributions of peoples of African descent in its construction of a racially mixed harmonious mestizo subject. The absence of Black Central Americans ${ }^{3}$ in Latinx Studies and Central American Studies reflects an epistemic violence inherited from Latin American mestizaje. The insurgence of AfroLatinx Studies is an intellectual and political response to the erasure and negation of Latinxs of African descent in the field of Latinx Studies. I call for a refashioning of AfroLatinidad that dismantles the dangerous allure of ethno-racial nationalism (e.g., Afro-[insert nation-state]) and that refuses cartographies of Blackness that map exclusionary geographies of Spanish-speaking Americas (“you must be Dominican, because you don’t look Guatemalan”). Drawing on oral history interviews, visual cultures, and social media, I demonstrate how, from the late 1950s to the present, transgenerational Garifuna New Yorkers' histories and politics of self-making 
highlight their struggles to negotiate, perform, and articulate their multiple subjectivities as Black, Indigenous, and Latinx. In the following section, I begin with a mid- $19^{\text {th }}$ century and early $20^{\text {th }}$ century history of anti-Black racism on Central America's Caribbean Coasts to argue that hemispheric travel from South (Central America) to North (United States) shapes how Garifuna New Yorkers negotiate and articulate their Blackness, Indigeneity, and Latinidad in the United States.

\section{Central America's Caribbean Coasts: Racialized Geographies of Anti-Blackness}

In Central America, Blackness and geography are intrinsically entangled with histories of Spanish colonialism, mestizo governance, and the alienation of Blackness to the Atlantic Coast (Gordon 133). Mestizaje as a racial discourse emerged in the early twentieth century in response to a larger hemispheric critique of US imperialism, which grounded Latin American's myth of racial democracy as a distinct marker of racial egalitarianism in the face of Jim Crow apartheid in the US (Hooker, Theorizing Race 158). Central American ideologies of mestizaje emerge in distinct geographies and historical moments. I turn to Honduras and Nicaragua in particular because the Caribbean Coasts become an explicit demarcation of Black geography's detachment from the mestizo nation-state both discursively and geographically. In “'Beloved Enemies': Race and Official Mestizo Nationalism in Nicaragua," political theorist Juliet Hooker charts the absence of costeños (Creole/Afro-Caribbean and Indigenous Nicaraguans) in Nicaragua's formulation of mestizaje. She coins the term "mestizo multiculturalism" to highlight the contradictions of Nicaragua's 1987 move to become one of the first Latin American countries to adopt multicultural citizenship reforms. These reforms assigned special collective rights to Black 
and Indigenous communities on its Atlantic Coast, while maintaining mestizo culture as the hallmark of national identity in the company of racial and cultural diversity.

The Atlantic coast of Nicaragua is marked as geographically distinct in the landscape of Nicaraguan mestizo nationalism. British colonialism on Nicaragua's Caribbean Coast produces a alterity that marks produced there a[MOU1][PJLO2] cultural, religious, linguistic, and racialized culture different from the afterlife of Spanish colonialism in Nicaragua's mestizo nationalism. Following independence from Spain in 1821, Nicaragua underwent a wave of domestic civil wars and governmental regimes that aimed to bring forth national unity and state formation. One of the best-remembered state-building efforts was the forcible "reincorporation" of the Atlantic Coast in 1894, an act of internal colonization on Black and Indigenous communities to assimilate into mestizo culture. 1894's forcible annexation made Spanish the official language and Catholicism the official religion on the Atlantic Coast. This legacy informs the vexed relationship Creole and Indigenous communities have with the mestizo nation-state; therefore, the shift to multiculturalism has been greeted with much-deserved skepticism. Despite the constitutional shift toward a multicultural paradigm, peoples of African descent remain geographically and politically marked as alien and foreign, and only exist on the Caribbean Coasts removed from the interior (Pacific Coast) of mestizo political power.

Historian Darío A. Euraque argues that the Honduran Congressional Act of 1926, which officially titled the national currency the Lempira, was an explicit response to the threat of Blackness by the growing banana economy on Honduras's Caribbean Coast. Euraque argues: In the 1920s the notion of an Indo-Hispanic mestizaje represented only an emerging elite discourse. However, the 1920s effort to officially designate Lempira as the "representative" of the "other race" in "our mestizaje" 
involved a local racism that drew on a postindependence rejection of blackness, and especially a rejection of Garifuna blackness as a more local and immediate racial threat. (243)

Black Hondurans were a great source of anxiety at a time when the Caribbean Coast was gaining financial and political independence from the capital city of Tegucigalpa through the presence of US-owned banana companies. This anxiety also fueled the deportation of thousands of West Indian migrant laborers, mostly from British Honduras (present-day Belize) and Jamaica. Honduran anti-Blackness made Garifuna and Creole communities on the Caribbean Coast vulnerable to border patrol harassment and increased their risk of deportation (Chambers 74). At distinct moments of nation-building in Nicaragua, Honduras, and the rest of the isthmus, Blackness was a great source of discursive and economic anxiety. ${ }^{4}$ This continues to be the case to this day.

Anti-black racism in Central America informs the political mobilization and self-making processes of Garifuna New Yorkers. Anti-black racist histories are embodied memories that are transmitted generationally through oral histories. Garifuna New Yorkers negotiate and contradict their Blackness, Indigeneity, and Central Americanness based on that historical legacy, which shapes contemporary racial and racist discourse on the isthmus and in its diasporas. The political and cultural histories of Central America's Caribbean Coasts are present in [Mou3]New York City and throughout the rest of the Garifuna diaspora in the United States, directly shaping how US Garinagu engage and mobilize alongside other Black Caribbean, African American, and Latinx communities. In the following section, I turn my attention to Garifuna of mostly Honduran and Guatemalan descent born and raised in New York City (Eastern Brooklyn and the South Bronx) and analyze their diasporic processes of self-making Garifunaness in the company of African 
Americans, Dominicans, Jamaicans, Puerto Ricans, and Ghanaians. Afro-Latinx Studies is a political project whose origins stand outside of the disciplinary boundaries of the academy and whose intellectual impulse is to disrupt the absence of Latinxs of African descent in the field of Latinx Studies. ${ }^{5}$ I therefore ask how transgenerational Garifuna New Yorkers negotiate and articulate their Central Americanness and Garifunaness simultaneously. How does an explicit politics of rejecting AfroLatinidad for Garifunaness reinscribe Garifuna exceptionalism and ethno-racial nationalism?

\section{$\underline{\text { A Note on Garinagu Indigenous Blackness }}$}

$\underline{\text { Blackness and Indigeneity remains codified and ascribed as mutually exclusive racial }}$ categories and identities in the Americas. Garifuna folks are persistently constructed as an anthropological puzzle because their contradictory and choreographed negotiations as simultaneously Black Indigenous peoples present a richly compelling conundrum. ${ }^{1}$ However, as we deepen our historical and contemporary understandings of Black and Indigenous peoples throughout the Americas we can begin to dismember these colonial logics of racial compartmentalization and excavate multiple Black Indigenous histories, cultures, and politics. Garinagu articulations and self-makings of Indigenous Blackness are not unique to Garifuna, as $\underline{\text { there are several communities of African descent throughout the Americas whose Indigenous }}$ ancestry and lineage shape their political consciousness as Black Indigenous, such as Gullah/Geechee, quilombos in Brazil, Jamaican maroons, palenques in Colombia, and Seminoles, among others. Furthermore, it is important to note that throughout this dissertation my interlocutors - who mostly find themselves living or having lived in New York City — understand $\underline{\text { their Garinagu Black Indigeneity as one rooted in the Caribbean, Central America's Caribbean }}$

\footnotetext{
1 Mark Anderson, Black and Indigenous: Garifuna Activism and Consumer Culture in Honduras. (Minneapolis: University of Minnesota Press, 2009).
} 
Coasts, and the United States. The terms used by my interlocutors are multiple, and include: negro indigena [Indigenous Black], afroindigena [Afroindigenous], Black Indigenous/Afro-Indigenous, and Black Carib. These variations point to the multiplicity of geographies, spaces/places, and racial identity formations that Garinagu engage. In the context of Honduras and the rest of Central America's Caribbean Coasts, for example, Garinagu articulations and self-makings of Black Indigeneity are performed, negotiated, and lived in distinct ways from U.S.-based Garifuna folks. In Central America, Garinagu notions of (Black) Indigeneity are bound to land and cultural traditions: claiming indigeneity is a political move to claim land rights, tenure, and titles. In the United States, and more specifically in New York City, Garifuna folks use Indigeneity (read: Carib Arawak lineage) as a marker of cultural alterity within Blackness. Claiming Indigeneity is thus performing different political subjectivity labor in these different geographical racialized spaces. My framing of hemispheric Indigenous Blackness thus comes directly from my interlocutors. In the context of Central America's Caribbean Coasts, Garinagu communities articulate their Caribbean Indigeneity as one bounded to land rights; this is why Garifuna Settlement Day originates on the Atlantic Coast of Central America (Belize to be precise) as an $\underline{\text { Indigenous articulation of land tenure and rights. Garifuna Indigeneity in Central America is used }}$ to gain discursive, ontological, and material land/territory vis-à-vis an articulation of indigeneity as an ancestral heritage and a contemporary identity. Ancestral land/territory is the epicenter of how Garifuna Indigeneity is materially articulated on Central America's Caribbean Coasts. However, in the United States there is a shift in how Garinagu articulate and invoke their Indigeneity, which is rooted in St. Vincent. In the United States, Garifuna Indigeneity is articulated, invoked, and performed as an Othered formation of Blackness. Garifuna Indigeneity in the United States is constructed and performed as a signifier of Caribbeanness, of exceptional 
marronage, and locates a Caribbean geographical site of Garifuna ethnogenesis: St. Vincent. Therefore, in the United States Garifuna Indigeneity finds an imaginary homeland in St. Vincent as not solely a site of ethnogenesis but a nostalgia for marronage and Black Indigeneity. Garinagu articulations and performances of Black Indigeneity are not universal. They are distinct based on the specific geographies in which Garinagu folks find themselves. Garifuna communities in Los Angeles, Houston, Chicago, and New York City are going to have different expressions of and relationship to their Indigeneity based on the racialized geographies of those spaces, while retaining commonalities. Black Queer Feminist theorist Tiffany Lethabo King notes that:

"genocide and slavery do not have an edge. While the force of their haunt has distinct feelings at the stress points and instantiations of Black fungibility and Native genocide, the violence moves as one. To perceive this distinct yet edgeless violence and its haunting requires a way of sensing that allows moving in and out of blurred and sharpened vision, acute, and dulled senses of smell. It requires that taste buds at the back of the throat and the pinch of the acidic in the nerves of the jawline. Edgeless distinction is a haptic moment, shared, and a ceremonial Black and Indigenous ritual." (King)

King's provocation to pay attention to the edgeless colonial hauntings of Blackness and Indigeneity is generative as we think about the ways in which Garifuna folks negotiate and contradict their articulations and self-makings of Black Indigeneity. The Black Indigeneity of Garifuna folks is a significant marker of distinction on Central America's Caribbean Coast (and in the United States). In the context of Honduras, Garifuna have politically mobilized with the nation$\underline{\text { state to gain constitutional rights to ancestral lands and inclusion into the polity through a politics }}$ 

cultural heritage.

\section{The Insurgency of Black Latinidad: Unsettling Hemispheric Mestizaje}

"No matter your race because you know you're Latino" N.O.R.E. (October 2004)

"Si tú eres Latino, saca tu bandera." Gente de Zona (April 2015)

Latinidad in the United States is built on, travels[Mov4][PJL5], and performs the ideological legacies of Latin American mestizaje as a political project of racial mixture that seeks to distance itself from its northern imperial neighbor: Jim Crow apartheid (Hooker, Theorizing Race). Mestizaje also romanticizes Spanish colonialism and the caste system in its national memory of a past Indigenous culture and civilized Spanish conquest, omitting the gendered and sexualized violence of Spanish colonialism in the Americas from this historical memory (Mendoza). The negation of Blackness within the project of mestizaje or the recovery of it, as in the example of Mexico's Third Root, problematizes mestizaje as a racial project that imagines racial mixture as the solution to racism and racial inequalities. It is precisely in the struggle with the negation and erasure and for the recovery of Blackness in Latin America and US Latinidad that Afro-Latinx Studies insurgency becomes a necessary political and intellectual project of Black political mobilization.

In her New York Times article "For Many Latinos, Racial Identity Is More Culture Than Color," Mireya Navarro writes that, in the context of the United States, 
the census categorizes people by race, which typically refers to a set of common physical traits. But Latinos, as a group in this country, tend to identify themselves more by their ethnicity, meaning a shared set of cultural traits, like language or customs. So when they encounter the census, they see one question that asks them whether they identify themselves as having Hispanic ethnic origins and many answer it as their main identifier.

Here we see a persistent dilemma within hemispheric constructions of Latinidad: its "ongoing production" (to borrow from Stuart Hall[ETG]|PJLO7]) is rooted in ethnic signifiers in hopes of evading racial discourse for a raceless imaginary of ethnicities. The problematic news story argues that Latinos are so racially mixed that their ethnic differences mark them much more deeply than race in the United States. This is a narrative supported by the general notion that racial discourse and racism do not exist in Latin America and the Caribbean the way they do in the United States, and that any inequalities that do exist result from class and ethnic differences. This trope of Latinx racial exceptionalism as simply not fitting into US racial categories is based in a hemispheric project of mestizaje that is haunted by the mythical illusion of racial democracy (read: racial paradise) in the shadow of Jim Crow's black/white binary. In the United States, nonBlack Latinx peoples mobilize for a census category that transcends US racial categories, distancing themselves from and opposing the histories of racial formation by aspiring to racialized sameness (read: Hispanic/Latino) vis-à-vis ethno-racial nationalist identities (read: Puerto Rican, Mexican-American, etc.) in a continued negation of Black and Indigenous Latinx peoples. 
While scholarly production on Black Latin America has enjoyed a long tradition since the nineteenth century, equivalent scholarship on Black Latin Latinxs in the United States and their descendants remains absent. It is this absence that highlights the political and intellectual necessity of Afro-Latinx Studies, which involves the lived experiences of Latinxs of African descent whose transgenerational migrations, routes, and lineages are located south of the US border, as a means to disrupt homogenized Latino racial exceptionalism. Afro-Latinx Studies opens a space to analyze how Black Latinxs born and raised in the United States can potentially unsettle the media-infused narrative of African American and Latinx conflict, which foments a divisive majority-minority dichotomy.

In their groundbreaking edited volume The Afro-Latin@Reader: History and Culture in the United States, Miriam Jiménez Román and Juan Flores give us a useful introductory definition of Afro-Latin@s as "people of African descent in Mexico, Central and South America, and the Spanish-speaking Caribbean, and by extension those of African descent in the United States whose origins are in Latin America and the Caribbean" (1). Building upon this definition, AfroLatinidad emerges as an insurgent analytic that dismantles centuries of discursive and scholarly erasure and negation of Blacks and Blackness in Latin America and unsettles US Latinidades' investment in an imagined racially harmonious project that reinscribes ethnonationalism as exceptional transcendence of US racial formations (López Oro 62). AfroLatinidad complicates Blackness as a site of rupture in the United States by taking a hemispheric turn to deepen our understanding of the histories, politics, and transmigrations of Blackness in the Americas.

I now turn to three moments in which transgenerational Garifuna New Yorkers negotiate and articulate their multiple subjectivities as an act of refashioning AfroLatinidad. 


\section{Garifunizando AfroLatinidad: The Politics of Self-Making Garifuna New Yorkers}

Many of the terms, including Latino/a, we use today were created (or influenced) by those who've colonized us. In using the term negra, or afrodescendiente, I'm choosing to without a doubt center Blackness. Identity isn't clear cut. It's complex and multilayered. As I journey through life, just as my current experiences influence how I identify, new encounters and knowledge will further shape it. No matter which term I use, my pride in my African roots will forever be a constant. Let there be no confusion as to who I am: a Black woman. In the eternal words of Victoria Santa Cruz, "Sí, soy negra. Negra soy."

-- Janel Martínez, “'Negra Soy’: Why I’ve Moved Away from the Term Afro-Latina"

New York City is home to the largest Garifuna community outside of Central America's Caribbean Coast. This geographic and demographic distinction matters for many historical and political motivations. It highlights an understudied history of Garifuna Central American transmigrations to New York City that begins in the late 1950s with the economic collapse of the US-owned Fruit Companies, which ignited a Great Migration of Black Central Americans from South of the US South. ${ }^{6}$ In other words, Garifuna folks are US imperial subjects before arriving at the shores of the United States. Within the broader racialized geographies of US Central 
Americanness, New York City is not imagined as a US Central American space due to the dominance there of Caribbean Latinx communities.

On February 23, 2014, the image below was posted on the popular Facebook page "Garifuna TV Page," where news on gatherings and community events in the US (New York City, Chicago, Houston, New Orleans, Miami, and Los Angeles) as well as in Central America are shared. The Facebook page also promotes Garifuna culture and music, giving publicity to local Garifuna musicians, artists, and activists. 


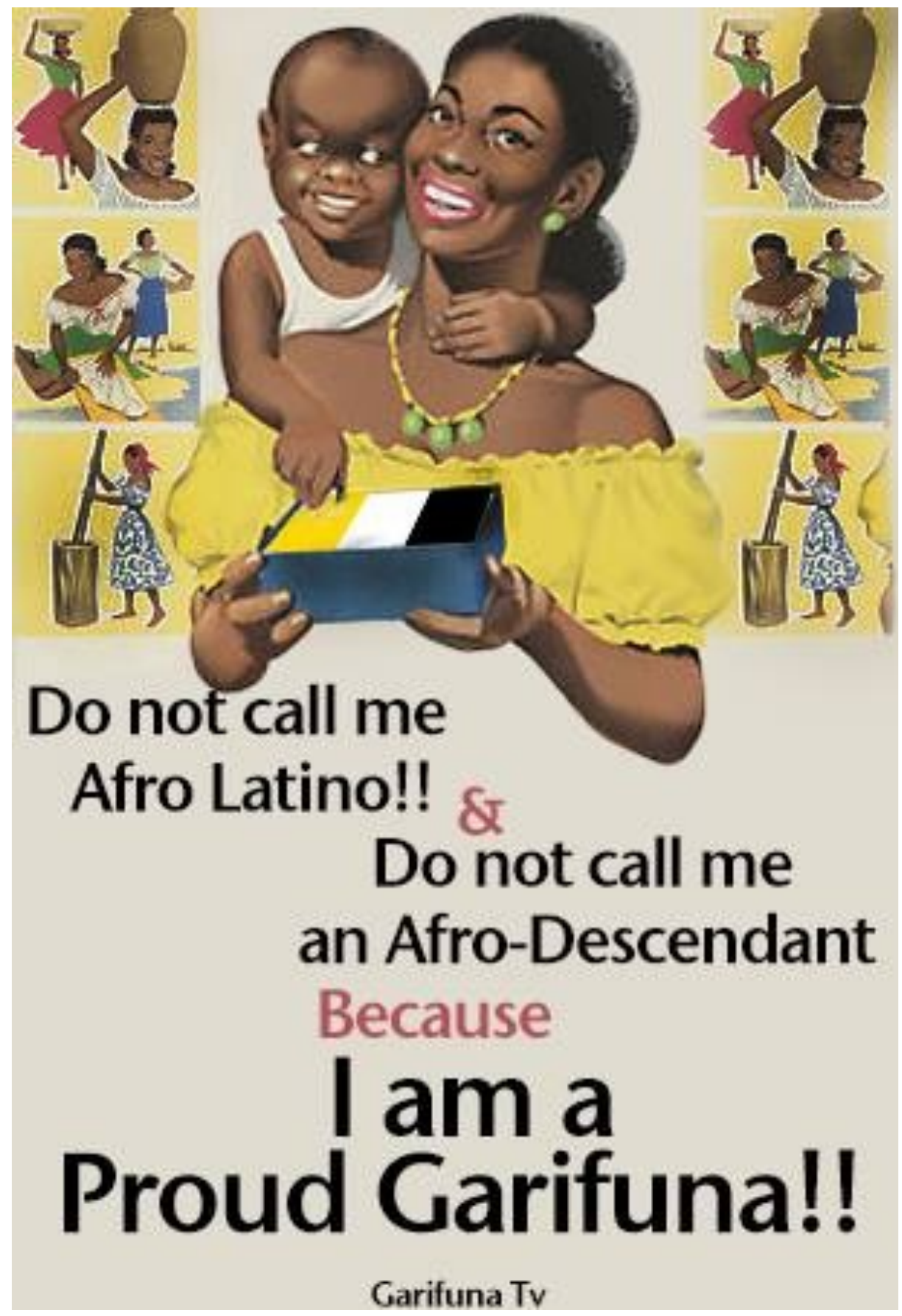

Fig. 1: Facebook post on Garifuna TV page, February 23, 2014.

The posting was in response to an ongoing debate in Garifuna social media spaces about Afrolatinidad. The statement, "Do not call me Afro Latino!! \& Do not call me an AfroDescendant because I am a Proud Garifuna," is accompanied by visuals of Garifuna culture and 
traditions, including the symbolic Garifuna flag and its colors (yellow, white, and black) and activities such as mashing plantains for a plate of machuca (hudutu), rasping coconut on a board to make either bread or stew, and carrying baskets. These are all images of labor done by Garifuna women; the only male presence in the image is the young boy being carried on his mother's back. The Garifuna tropes invoke nostalgia for Central America's Caribbean Coast and bestow historical weight onto diasporic Garifunaness.

The image was created by Ana Castillo, a US-based Garifuna poet from Honduras. The loss of Garifuna culture and language to American culture, specifically African American culture, has been an ongoing concern of the generation of Garifuna Central American immigrants of the 1960s. The clear rejection of AfroLatinidad and Afrodescendants in this image is a deeply significant assertion that points to the centuries of anti-black racism and violence experienced by Garifuna Central Americans in the isthmus. The assertion of an exclusively Garifuna epistemology matters here as a point of disruption into a category that does not capture Garifuna Black Indigeneity, and it also reveals the political mobilization of Garifuna communities in Central America and in the United States in the effort to preserve their culture, language, and history. There is a generational concern here that something is lost in the United States, that values, customs, language, traditions, and music are slowly being erased because of American assimilation and because families are no longer living in their hometowns on the Caribbean Coasts. It is interesting that the categories of Afro-Latino and Afro-descendant are presented together; their conjunction conveys a reinscription of Garifuna pride throughout the Americas. "Afro-Latino," a term mostly used in the United States, and "Afro-descendant[ET8][PJLO9]," which is mostly used in Latin America, have parallel political projects of insurgency that respond to the erasure and absence of Blacks and Blackness in Latin America and US Latinidad. However, here 
Garifuna folks are not interested in investing into a project that from its inception has erased, excluded, and voided their existence. The phrasing "Do not call me Afro Latino and Do not call me Afro-descendant, I am a Proud Garifuna" is an effective political affirmation of visibility and recognition at a moment when AfroLatinidad and Afrodescendant have taken center stage as allencompassing umbrella terms. Garifuna folks are uneasy about the way both terms erase/silence/footnote the specific histories of Blackness in Latinx Americas. More importantly, the phrase "I am a Proud Garifuna" builds on the political genealogies of the US Black Power Movement of the 1960s and 1970s, echoing James Brown's iconic vocals in "Say It Loud, I'm Black and I'm Proud." "I am a Proud Garifuna" is an explicit response to the historical and contemporary manifestations of mestizo supremacy and anti-Black racism in Central America, which remains present today in spite of a multicultural shift. The echo of the US Black Power Movement here unearths the hemispheric influences of African American political thought and formations. It also exemplifies how Garifuna New Yorkers and those throughout the rest of their diaspora in the United States engage directly with US Black history, culture, and politics.

Janel Martínez's invocation of her Blackness quoted in the epigraph of this section is of great transgenerational diasporic importance. Her rejection of the term "AfroLatinx," especially at a moment of hyperawareness, points to her desire to center her Blackness as something other than a racial fetish. It speaks to the broader politics of the way Garinagu New Yorkers [mov10]and those in Central America negotiate and articulate their Blackness as a political project of membership to the larger African diaspora, rooted in the racialized lived experiences of being Black. Indigeneity, although it is a simultaneous Garifuna identity in these instances, takes a back seat to a politics of Blackness that highlights an interpellation as always already Black. 


\section{“Ain’t I Latina?”: Negotiating Central Americanness vis-à-vis AfroLatinidad}

Aida Lambert, a Garifuna woman born and raised in Honduras, came to New York City in 1964 at a time when Central Americans, especially Garifuna folks, did not have much visibility in the ethnic pantheon of New York City's Latinidad. Aida Lambert forms part of the second largest wave of Garifuna New Yorker transmigrants who arrived a few years prior to the economic collapse of the United Fruit Company. She first lived in Eastern Brooklyn and later, when she married, moved to East Harlem with her husband and children. In her autobiographical essay "We Are Black Too: Experiences of a Honduran Garífuna," Lambert illustrates the nuanced relations between African Americans and Spanish-speaking immigrants. Lambert was a founding committee member of Desfile de la Hispanidad [Hispanic Parade]. The Annual Hispanic Parade in October emerged mid-1980s when NuyoRicans and recent migrants from Puerto Rico wanted to exhibit their culture, work ethic, and racial differences from their African American neighbors. Lambert's involvement developed out of her language barriers with other English-speaking Blacks and her cultural and linguistic bond with Puerto Ricans and Dominicans:

I have found that even though you are Black, the fact that you are Latina means to them [African-Americans] that you are of another race ... even at home, in Honduras, our Garífuna culture, and our language, is losing ground and becoming less and less familiar. And here it is even more so. My own children, as much as I try to keep the culture alive, they have their own lives and often forget whatever they learn. Not to mention my grandchildren, who were born here. I warn them about my experiences with African Americans, but they play with them, are influenced by them, and join them. They make friends with them, they identify with them, in 
the way they dress, and talk, and the music they listen to. And what can I

do, I have to let them choose their own cultural preferences. (433)

Lambert's testimonio is telling of her generation of Garifuna Central American immigrants and their engagement and inclusion with Puerto Rican and Dominican aspirations of social mobility. The generations of Garifuna New Yorkers following Lambert's arrival to Brooklyn and Harlem negotiate Latinidad in multiple ways that simultaneously reject and interject into Latinidad as a marker that makes Garifuna Blackness distinct from the Blackness of African Americans, while simultaneously using Garifunaness as a means of distancing from mestizo Latinidad and AfroLatinidad. Her feeling of being rejected by Black Americans and accepted by Puerto Ricans is a significant act of remembrance for a number of reasons, particularly because Garifuna Central Americans migrate to the United States at the intersections of anti-Black racism, nondemocratic governments, and economic instability. Lambert's remembering of solidarity and support from Puerto Ricans is not a universal narrative according to Spanish-speaking Black immigrants, who continued to experience anti-Black racism from their own countrymates in the United States. The best-known example is Arturo Alfonso Schomburg, a Black Puerto Rican who migrated to Harlem in 1891 but, in contrast to Lambert, felt rejected by other Spanishspeaking immigrants and embraced by African Americans and Afro-Caribbeans (HoffnungGarskof). Aida's generation resisted being labeled African American and maintained the household mantra, "somos negros pero no como aquellos" (we are Black but not like them), "them" being African Americans. This narrative does not remain true for second and especially third generation Garínagu, as their interpellation as Black Americans creates interstitial spaces between their Blackness, Garifunaness, and Latinidad. They never fully belong in any of these 
categories because the United States is a dislocation of birthplace, citizenship, and a fragmented home.

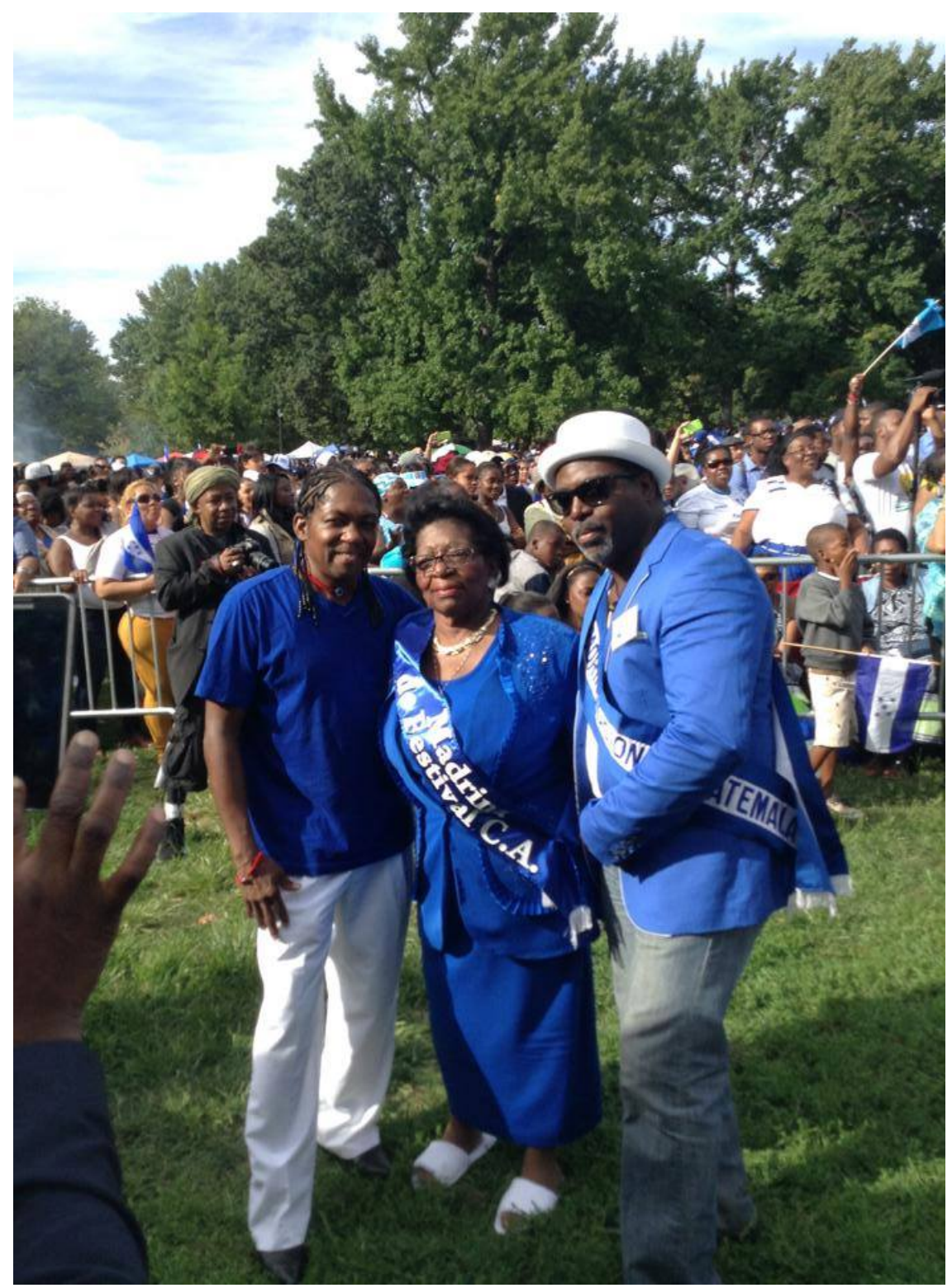

Fig. 2. Aida Lambert in the center being honored in the 2014 Central American Parade \&

Festival in Crotona Park, Bronx as Madrina de Festival Centroaméricana. Photo courtesy of the author. 
Janel Martínez is a Garifuna woman of Honduran descent, born and raised in the Bronx, and daughter of Garifuna Honduran immigrants from the 1970s generation. She is the creator of “Ain't I Latina?” an online destination created by an Afro-Latina for Afro-Latinas, inspired by the lack of representation in both mainstream and Spanish-language media. Martínez is a multimedia journalist whose work has been featured in both African American media sites, such as The Root, Black Enterprise, Madame Noire, and in Latinx media sites, such as Cosmopolitan for Latinas, Remezcla, and NPR's Latino USA. The very question that inspires Martínez's online site, and which provocatively connects her to Sojourner Truth's “Ain't I a Woman?" shows the importance of disrupting mestizo Latinidades which erase peoples of African descent. Martínez's Black Latinidad is articulated not as separate from the Black identity of African Americans but very much in the company of African American and other non-US Black lived experiences in the United States. Her travels to her parents' hometown communities on the Caribbean Coast of Honduras in Ciriboya and Irionia deepened her Garifuna political identity. She notes, "Garifuna was never an identity I had to unearth; it was a culture and way of being I experienced within and all around me" (Martínez, "This is What it's Like"). Martínez points to her home life as a site of Garifuna self-fashioning where food, language, and traditions are preserved in the intimacies of her mother's kitchen and in family gatherings in her parents' living room. After her grandmother's passing and the ensuing beluria, a Garifuna spiritual tradition to celebrate life in and after ancestral deaths, Martínez's interest in learning about Garifuna life and history continues.

Martínez's journalistic work has examined the complexities of being raised Garinagu in the United States, where one's identity is frequently demeaned or marginalized. Grounded in her identities as Garifuna and Black Latina, Martínez explores the complexities and multiplicities of 
diasporic linkages with other Black Latinxs and the intersectionality of race, ethnicity, country of birth, and nationality. While Martínez acknowledges that presuming a common AfroLatinidad, especially one that does not center Blackness (Martínez, “Negra Soy”"), runs the risk of homogenizing Latinxs of African descent, her work still notes that refashioning AfroLatinidad calls for an expansive and hemispheric Blackness in the Americas instead of simply relying on a politics of inclusion into Latinidad.

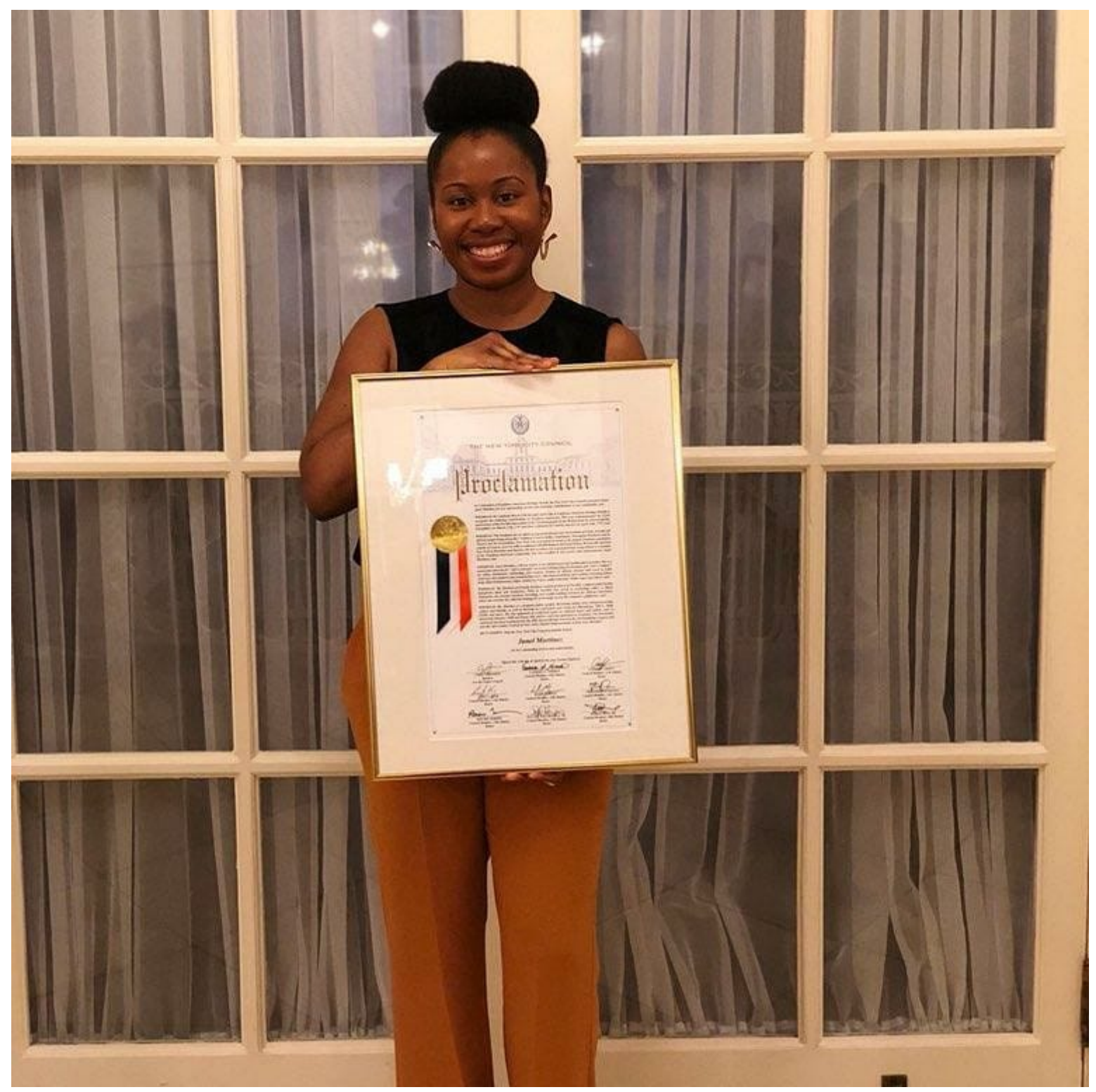


Fig. 3. Janel Martínez on April 12, 2018 being awarded a Proclamation by New York City

Council Member in Vanessa L. Gibson for her activism and cultural work in preserving Garifuna history and culture in New York City. Photo courtesy of the author.

\section{Hemispheric Black Latinidades: Garinagu New Yorkers Presente}

On July 13, 2018, I was invited to participate in a Presidential Plenary titled "US Central Americans, Invisible, and Silent No More" for the Latina/o Studies Association biannual meeting. I began my comments with the following provocation to problematize the absence of Black Central Americans in the scholarship on US Central Americans:

My Central America is Caribbean. My Central America is a Caribbean Coast whose natural resources and peoples have and continue to be exploited by US imperialism. My Central America is Black, Black Indigenous to be exact, whose descendant's survivors of the transatlantic slave trade and Carib-Arawak indigeneity on the Antillean island of St. Vincent and whose marronage and exile call Central America's Caribbean Coast: home. To be Garifuna is to be Caribbean and Central American simultaneously. I am the grandchild of banana workers from Tela and Balfate, Honduras whose transmigrations to Harlem, New York, in 1964 was made possible by the political mobilization of Garveyism and whose parents met in Bedford-Stuyvesant, Brooklyn in 1982. My Black Central America is also New York City.

My articulations of Black Central America on the isthmus and in its diasporas builds on centuries of anti-Black racism and erasure of our existence. Aida Lambert, Janel Martínez, and Vielka 
Cecilia Hoy all articulate a politics of Black Central Americanness that is made and remains invisible in the face of a mythical all-inclusive Latinidad. Lambert's political mobilization alongside Puerto Ricans, Dominicans, and other mestizo Latinx New Yorkers animates her desires to negotiate her Black Honduranness in the Desfile de la Hispanidad, where her activism allowed a Garifuna Honduran woman to win the beauty pageant contest in 1994. Martínez's negotiation and articulation of her Black Latinidad engages a hemispheric project that centers Blackness in the Americas with an inclusionary praxis into Latinidad. Garifuna New Yorkers of Central American descent are marked by their transgenerational differences and bounded by a Garifunaness that disrupts hegemonic racial and ethnic subjectivities.

${ }^{1}$ I refer to a violence that is both physical and epistemic, pointing to the centuries of land dispossession, US imperialism, and erasure from national subjecthood. Central Americans of African descent are in the margins of the histories of transmigrations and political movements in the isthmus and their diasporas.

${ }^{2}$ Garifuna epistemology is rooted in Black Indigeneity, where Blackness is marooned in the Americas, as the collective memory of ethnogenesis on St. Vincent: being descendants of shipwrecked slaves, an important marker of alterity and problematic divorcing of plantation slavery in the Americas. The Garifuna notion of maroonage is foundational to Garifuna Black Indigeneity as it invokes an act of shipwreckedness and eventual hybridity with Carib Arawak Indigenous peoples on St. Vincent in the $15^{\text {th }}$ century.

${ }^{3}$ I reference the homogenized term Black Central Americans or Central Americans of African descent, which does not detail the multiplicity of Black Central American communities. I do this with the political intent of affirming Blackness in a region of the Americas that is racialized as a non-Black space.

${ }^{4}$ This is the case even during the multicultural era, especially as Creole, Garifuna, and West Indian communities continue to fight for autonomy and inclusion.

${ }^{5}$ I only use the hyphen when referring to the field of study of Afro-Latinx Studies. I explicitly use Afrolatinidad and AfroLatinx to refer to peoples, histories, and cultures, because the hyphenation of AfroLatinidad/Afro-Latinx is a continued violence of erasure. A hyphen reinscribes the notion that "Black" and "Latinx" are mutually exclusive to each other. Here I build on conversations with Omaris Z. Zamora and Yomaira C. Figueroa about the idea that Blackness is always already present in our Latinidad. Hyphenation is a dislocation of Blackness in distancing from Latinidad and in this context more specifically from US Central Americanness.

${ }^{6}$ I refer to this understudied transmigration of Garifuna and Creole folks to the United States as a "Great Migration of Black Central Americans from South of the US South" to point to the various hemispheric Black migrations and to disrupt the grand narrative of a US-centered Great Migration. Throughout the Americas, there have been and continue to be "Great Migrations" of Black communities fleeing anti-black racism. 
Works Cited

Chambers, Glenn A. Race, Nation, and West Indian Immigration to Honduras, 1890-1940. Louisiana State UP, 2010.

England, Sarah. Afro-Central Americans in New York City: Garifuna Tales of Transnational Movements in Racialized Space. UP of Florida, 2006.

Euraque, Darío A. "The Threat of Blackness to the Mestizo Nation: Race and Ethnicity in the Honduran Banana Economy, 1920s and 1930s." Banana Wars: Power, Production, and History in the Americas, edited by Steve Striffler and Mark Moberg, Duke UP, 2003, pp. 229-250.

Figueroa, Yomaira C. Languages of Exile and Diaspora: A De Colonial Approach to Equatoguinean and Afro_Latin@Literature.2014.[ET11][PJL012]-University of California, Berkeley, PhD dissertationDecolonizing Diasporas: Radical Mappings of Afro-Atlantic Literature. Northwestern University Press, 2020.

Gordon, Edmund T. Disparate Diasporas: Identity and Politics in an African-Nicaraguan Community. The U of Texas P, 1998.

Gudmundson, Lowell, and Justin Wolfe. Introduction. Blacks and Blackness in Central America: Between Race and Place, edited by Lowell Gudmundson and Justin Wolfe. Duke UP, 2010, pp. 1-23.

Hale, Charles R. "Neoliberal Multiculturalism: The Remaking of Cultural Rights and Racial Dominance in Central America.” PoLAR, vol. 28, no. 1, 2005, pp. 10-28. JSTOR, www.jstor.org/stable/24497680. 
Hoffnung-Garskof, Jesse. "The Migrations of Arturo Schomburg: On Being Antillano, Negro, and Puerto Rican in New York, 1891-1938." Journal of American Ethnic History, vol. 21, no. 1, Fall 2001, pp. 3-49. JSTOR, www.jstor.org/stable/27502778.

Hooker, Juliet. “'Beloved Enemies': Race and Official Mestizo Nationalism in Nicaragua.” Latin American Research Review, vol. 40, no. 3, 2005, pp. 14-39. Project Muse, doi:10.1353/lar.2005.0051.

Hooker, Juliet. Theorizing Race in the Americas: Douglass, Sarmiento, Du Bois, and Vasconcelos. Oxford UP, 2017.

Hoy, Vielka Cecilia. "Negotiating among Invisibilities: Tales of Afro-Latinidades in the United States.” Jiménez Román and Flores, pp. 426-430.

Jiménez Román, Miriam, and Juan Flores, editors. The Afro-Latin@Reader: History and Culture in the United States. Duke UP, 2010.

King, Tiffany Lethabo. The Black Shoals: Offshore Formations of Black and Native Studies, (Durham: Duke University Press, 2019).

Lambert, Aida. “We Are Black Too: Experiences of a Honduran Garifuna.” Jiménez Román and Flores, pp. 431-433.

Loperena, Christopher. "Radicalize Multiculturalism? Garifuna Activism and the Double-Bind of Participation in Postcoup Honduras." The Journal of Latin American and Caribbean Anthropology, vol. 21, no. 3, 2016, pp. 521-522. Wiley, doi:10.1111/jlca.12222.

López Oro, Paul Joseph. "Ni de aquí, ni de allá: Garifuna Subjectivities and the Politics of Diasporic Belonging.” Afro-Latin@s in Movement: Critical Approaches to Blackness and Transnationalism in the Americas, edited by Petra R. Rivera-Rideau, Jennifer A. Jones, and Tianna S. Paschel, Palgrave Macmillan, 2016, pp. 61-84. 
Martínez, Janel. “'Negra Soy': Why I’ve Moved Away from the Term Afro-Latina.” Remezcla, 17 Sept. 2018, remezcla.com/features/culture/negra-vs-afro-latina/.

Martínez, Janel. “This is What It's Like to Grow Up Garifuna.” 12 Apr. 2018, Mitú, fierce.wearemitu.com/identities/as-garifuna-woman-come-from-lineage-black-femalefighters-but-didnt-always-know/.

Mendoza, Breny. "De-Mythologizing Mestizaje in Honduras: A Critique of Recent Contributions." Journal of Latin American and Caribbean Ethnic Studies, vol. 1, no. 2, 2006, pp. 185-201. Taylor \& Francis, doi:10.1080/17442220600859361.

Navarro, Mireya. "For Many Latinos, Racial Identity Is More Culture Than Color.” The New York Times. 14 Jan. 2012, www.nytimes.com/2012/01/14/us/for-many-latinos-race-ismore-culture-than-color.html.

Zamora, Omaris Z.“(Trance)forming AfroLatina Embodied Knowledges in Nelly Rosario’s Song of the Water Saints," Label Me Latina/o, Special Issue: Afro-Latina/o Literature and Performance, Vol. VII, (Summer 2017): pp. 1-16. (Trance)formations of an AfroLatina: Embodied Archives of Blackness and Womanhood in Transnational Dominican Women's Narratives. 2016. The University of Texas at Austin, PhD dissertation.[ET13] 